\title{
New species of Rhaphiptera (Coleoptera, Cerambycidae) from the Caatinga biome
}

\author{
Francisco E. de L. Nascimento ${ }^{1}$ \& Freddy Bravo ${ }^{2}$
}

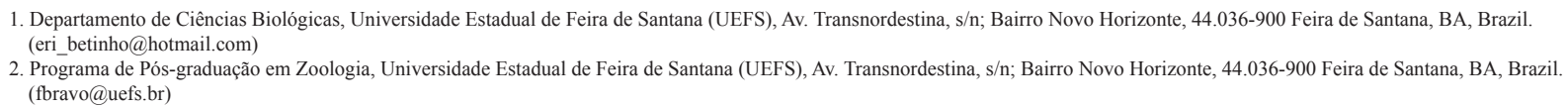

\begin{abstract}
A new species of Cerambycidae (Lamiinae) is described and illustrated from the Brazilian semi-arid of northeastern Brazil. Rhaphiptera delmari sp. nov. is recorded from Morro do Chapéu municipality in the Bahia State.
\end{abstract}

KEYWORDS. Chapada Diamantina, Lamiinae, long-horned beetles, Neotropical region, Brazilian semi-arid.

RESUMO. Nova espécie de Rhaphiptera (Coleoptera, Cerambycidae) do Bioma Caatinga. Uma nova espécie de Cerambycidae (Lamiinae) do Semiárido do Nordeste do Brasil é descrita e ilustrada. Rhaphiptera delmari sp. nov. é registrada do município de Morro do Chapéu no estado da Bahia.

PALAVRAS-CHAVE. Chapada Diamantina, Lamiinae, cerambicídeos, Região Neotropical, Semiárido brasileiro.

Rhaphiptera Audinet-Serville, 1835 (Lamiinae, Pteroplini) is a South American genus of Cerambycidae comprising 26 described species and it is known from French Guiana, Peru, Bolivia, Brazil and Argentina; one species of the genus was recorded from Panama in Central America (BeZARK \& Monné, 2013). Twenty one species of the genus are recorded in Brazil (states of Amazonas, Bahia, Espírito Santo, Goiás, Mato Grosso, Minas Gerais, Pará, Paraíba, Pernambuco, Rio Grande do Sul, Rio de Janeiro, Santa Catarina and São Paulo) (BezArK \& Monné, 2013). The species of Rhaphiptera are recognized by the following characters: antenomere III longer than the other flagellomeres; protibia with apical and subapical projections; femora with median area elongated; base of elytron without granulations (FraGOSO \& Monné, 1984). Six species have been recorded from state of Bahia: Rhaphiptera albipennis Breuning, 1947, Rhaphiptera oculata Gounelle, 1908, Rhaphiptera nodifera Audinet-Serville, 1835, Rhaphiptera affinis Thomson, 1868, Rhaphiptera apeara Galileo \& Martins, 2011 and Rhaphiptera melzeri Fragoso \& Monné, 1984 (BEZARK \& MonNÉ, 2013). The latter two species are known only from their type localities in state of Bahia (Fragoso \& Monné, 1984; Galileo \& Martins, 2011). We describe here a new species of Rhaphiptera from the semiarid region of Bahia.

\section{MATERIALS AND METHODS}

The specimens studied were deposited in the Coleção Entomológica Professor Johann Becker, Museu de Zoologia da Universidade Estadual de Feira de Santana, Bahia, Brazil (MZFS). The male genitalia of the holotype was cleared with hot $10 \%$ sodium hydroxide for 10 minutes and neutralized with acetic acid $20 \%$, and, then, transferred to glycerin for further dissection and examination. The genitalia was subsequently transferred to a microvial containing glycerin and pinned beneath the specimen. The terminology of the male and female genitalia follows Galileo (1987); the term phallobase in male genitalia of SNOdGRASS (1957) is preferred to "peça anelar" of Galileo (1987). Photomicrographs were obtained using a Leica DFC 295 video camera coupled to a Leica M205C stereomicroscope. The photos were combined using Leica Application Suite V3.Ink software. One paratype of the new species is deposited at Museu de Zoologia da Universidade de São Paulo, São Paulo, Brazil (MZSP) and the other specimens are kept in MZFS.

\section{RESULTS AND DISCUSSION}

\section{Rhaphiptera delmari sp. nov.}

(Figs 1-9)

Etymology. Named in honor of Irmão Marista Delmar a humanist and environmentalist from Morro do Chapéu, the type locality of this new species.

Diagnosis. Body pubescence whitish to yellowish; superior lobe of compound eyes with four rows of ommatidia; lobes separated one from another by approximately three times their individual widths; elytra anterior gibbosities, with tufts of black, Y-shaped bristles and bordered by yellowish pubescence; elytra lack transversal maculae; fore tibia with medial and internally granulose protuberances.

Description. Male (Figs 1-9). Total length 14.00 $\mathrm{mm}$; prothorax width $3.20 \mathrm{~mm}$; prothorax length 3.40 $\mathrm{mm}$; elytron length $10.00 \mathrm{~mm}$; humeral width $3.50 \mathrm{~mm}$. Body elongated, not depressed. Integument blackish-brown, dorsally with bicolor pubescence, whitish to yellowish.

Head. In dorsal view, shorter than prothorax, uniformly punctate; punctures sparse. Area around eyes yellowish. Coronal suture extending to occipital region, sometimes only slightly evident due to the presence of dense 
pubescence. Superior eye lobe with four rows of ommatidia, and lobes separated by approximately three times their own widths. Punctuations of interocular area coarse and irregular. Punctuations above eyes with long black bristles. Antenna exceeding elytron apex, with 11 segments, the eighth ending at the elytron apex. Antenniferous tubercles prominent. Antennal pubescence whitish, with long bristles on the internal margin. Antennal segments with darkened apices. Segment length ratios (male): 17:4:29:28:26:25: 19:18:17:16:19.

Thorax. Prothorax longer than wide, with coarse and sparse punctuations. Pubescence whitish to yellowish, uniformly distributed; lateral spines moderately developed, rounded with blackish apices; three dorsal tubercles forming a triangle, two of them anteriorly located, with shiny and blackish apices; posterior tubercle present. Procoxal cavity closed, slightly rounded and laterally angular; mesoternal cavity open. Scutelum with dense, yellowish pubescence. Elytra approximately 3.54.0 times the length of prothorax; external margins of elytra subparallel, with coarse punctuation pubescence predominantly yellowish in this area, with truncated apex; basal 1/5 of elytra with coarse punctuations and predominantly yellowish pubescence; basal $1 / 3$ of elytra with gibbosities, crowned with tufts of black bristles, with yellowish, Y-shaped pubescence (Fig. 4). Humeri with spines projected upwards. Mesepimeron and metepimeron with dense yellowish pubescence; mesesternum whitish. Tibiae and femora with whitish pubescence; protibiae ventrally with crenulate protuberance middle (Fig. 6).

Abdomen. Urosternites with whitish pubescence.

Genitalia (Figs 7-9). Median lobe depressed and arched in lateral view, approximately five times longer than wide. Parameres in dorsal view divergent, $1 / 5$ the length of tegmen; dorsal and ventral areas of parameres with long, blackish bristles on apical half. Roof slightly chitinous, $1 / 4$ the length of the parameres. Phallobase approximately $2 / 3$ the length of the tegmen, slightly sinuous, drop-shaped, wider apically.

Female. Similar to male except by the following characters: total length $12.50 / 13.50 \mathrm{~mm}$, prothorax length $2.60 / 3.00 \mathrm{~mm}$, elytron length $9.00 / 9.80 \mathrm{~mm}$, humeral width $3.30 / 3.50 \mathrm{~mm}$. Body more robust than male; antenna shorter than male, reaching the apex of elytron at the 10th antenomere; base of 5th urosternite with longitudinal, wide, and blackish furrow. A row of longitudinal blackish pubescence longer observed on the apical $1 / 3$ of the elytra of one paratype female.

Type material. Holotype male, BRAZIL, Bahia: Morro do Chapéu, cachoeira do Ferro Doido, $11^{\circ} 37^{\prime} 40^{\prime \prime}$ 'S; $41^{\circ} 00^{\prime} 02^{\prime \prime} \mathrm{W}, 900$ masl, Light trap, 24-25.VI.2009, Zacca, T., Oliveira, L., Casais G., Menezes E. colls. (MZFS); 2 paratypes female same data of holotype (MZFS, MZSP).

Type locality. Morro do Chapéu, a municipality situated in the Chapada Diamantina Mountain Range, state of Bahia, Brazil, at altitudes ranging from 480 to $1290 \mathrm{~m}$, with a mean annual rainfall of $726 \mathrm{~mm}$, with the rainy season from October to April (Velloso et al., 2002). The vegetation is diverse, ranging from dry forest or savanna vegetation formations on the slopes to savanna vegetation on the mountain tops (PrADO, 2003).

Remarks. Rhaphiptera delmari sp. nov. is morphologically similar to $R$. avicenniae Dalens \& Tavakilian, 2007, R. avicenniae Dalens \& Tavakilian, 2007 (French Guiana), R. scrutatrix Thomson, 1868 (Panama, French Guiana and Peru), and R. oculata, mainly by the gibbosities on the elytral base and subparallel external margins of elytra, with truncated (see BREUNING, 1961; TAVAKILIAN et al., 2007)

Rhaphiptera delmari sp. nov. can be distinguished from these three species by the following combination of characters: superior eye lobe with four rows of ommatidia; superior eye lobes separated by approximately three times their own widths; gibbosities with tufts of black bristles disposed in Y-shaped arrangements and surrounded by yellowish pubescence; elytra lack transversal maculae.

In $R$. avicenniae, the superior eye lobe has six to seven ommatidia; the superior eye lobes are separated by approximately their own widths; gibbosities lacking tufts of bristles; and elytra have transverse maculae (TAVAKILIAN et al., 2007). In R. scrutatrix, the superior eye lobe has six rows of ommatidia; the superior eye lobes are separated by approximately one and half times their own widths; gibbosities lack tufts of bristles; elytra without transverse maculae (BREUNING, 1961). In R. oculata, the superior eye lobe has six rows of ommatidia; the superior eye lobes are separated by approximately three times their own widths; gibbosities with tufts of brownish bristles; apical third of elytra with transverse maculae surrounded by dark strips (BREUNING, 1961; material examined: 1 exp. MZFS \#54677).

Acknowledgements. The authors would like to thank M.Sc. Eliomar Menezes (Universidade Estadual de Feira de Santana), for the photomicrographs, Antonio Santos Silva (MZSP) for providing bibliographic material, and Dr. Ubirajara R. Martins (MZSP) for his interest and support for this study. The first author received an Iniciação Científica grant from CNPq. Thanks are also due to the Programa de Pesquisa em Biodiversidade do Semiárido (PPBio/Semiárido) for financial support to field trips.

\section{REFERENCES}

Bezark , L. G. \& Monné, M. A. 2013. Checklist of the Oxypeltidae, Vesperidae, Disteniidae and Cerambycidae (Coleoptera) of the Western Hemisphere. Available at: < http://plant.cdfa.ca.gov/ byciddb/checklists/WestHemiCerambycidae2013.pdf $>$. Accessed on: 21.08. 2013.

Breuning, S. 1961. Révision des Pteropliini (Col. Cerambycidae). Pesquisas 9(5):5-60.

Fragoso, S. A. \& Monné, M. A. 1984. Sinopse do gênero Rhaphiptera Audinet-Serville (Pteropliini). Pesquisa Agropecuária Brasileira 19(9):1075-1083.

Galileo, M. H. M. 1987. Sistemática das tribos Meroscelisini e Anacolini (Coleoptera, Cerambycidae, Prioninae) nas Américas. II. Anacolini. Revista Brasileira de Entomologia 31(4):481-705.

Galileo, M. H. M. \& Martins, U. R. 2011. Novas espécies de Acanthoderini, Onciderini e Pteropliini (Coleoptera, Carambycidae, 

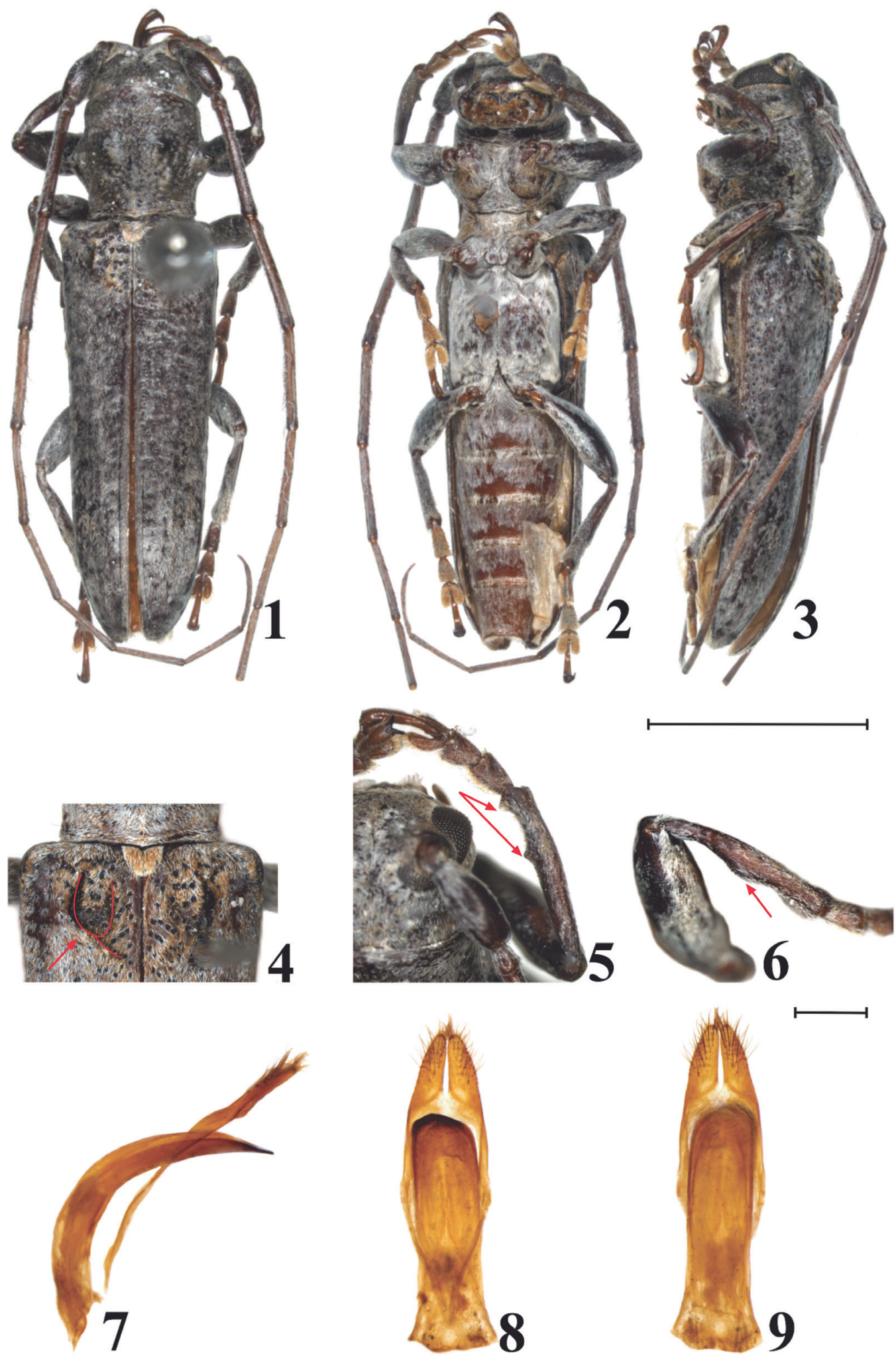

Figs 1-9. Rhaphiptera delmari, sp. nov., holotype male. Habitus: 1, dorsal view; 2, ventral view; 3, lateral view. 4, Elytra with Y-shaped gibbosity; 5 , protibia with apical and subapical projections; 6 , internal protuberance of the protibia; median lobe: 7, lateral view; 8 , ventral view; 9 , dorsal view. Scale bar: Figs $1-3=5.0 \mathrm{~mm}$; Figs $4-6=1.0 \mathrm{~mm}$; Figs $7-9=0.5 \mathrm{~mm}$. 
Lamiinae) do Brasil e da Bolívia. Acta Amazonica 41(1):175-182.

Julio, C. E. A.; Giorgi, J. A. \& MonNÉ, M. A. 2000. Os tipos primários de Cerambycidae (Coleoptera) da coleção do Museu Nacional - Rio de Janeiro. Publicações Avulsas do Museu Nacional 84:1-54.

Prado, D. E. 2003. As Caatingas da América do Sul. In: Leal, I. R.; Tabarelli, M. \& Silva, J. M. C. eds. Ecologia e Conservação da Caatinga. Recife, Editora da Universidade Federal de Pernambuco. p. 3-73.

SNODGRASS, R. E. 1957. A revised interpretation of the external reproductive organs of male insects. Smithsonian Miscellaneous Collections 135: $1-60$.

Tavakilian, G. L.; Dallens, P. H. \& Toroult, J. 2007. Les Raphiptera Audinet-Serville, 1835, en Guyane et description d'un nouveau genre affine (Coleoptera, Cerambycidae, Lamiinae, Pteropliini). Les Cahiers Magellanes 72:1-19.

Velloso, A. L.; Sampaio, E. V. S. B. \& Pareyn, F. G. C. eds. 2002. Ecorregiões: Propostas para o bioma Caatinga. Recife, Associação Plantas do Nordeste. 76p. 